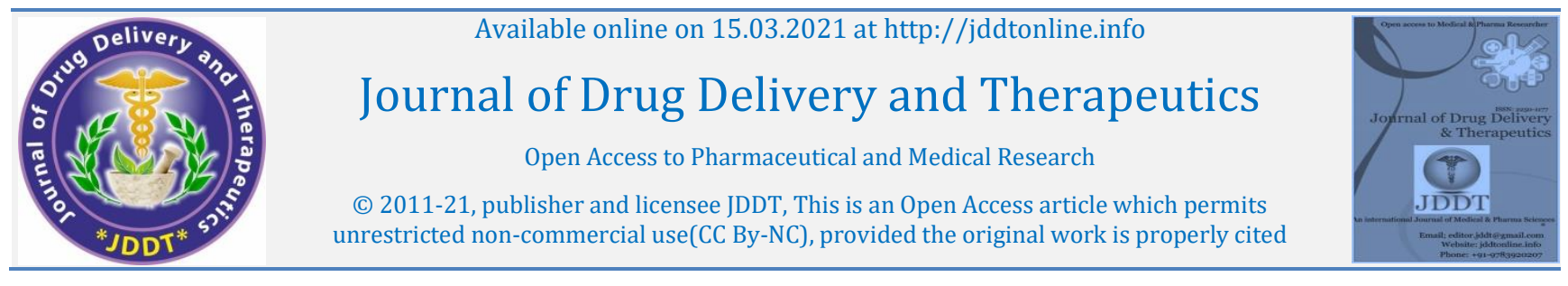

\title{
Medicinal Plants from Vettangudi Water Bird Sanctuary in Sivagangai District of Tamil Nadu, Southern India
}

\author{
Shanmugam $\mathrm{S}^{1 *}$, Muthupandi $\mathrm{CP}^{1}$, Eswaran $\mathrm{VM}^{2}$, Rajendran $\mathrm{K}^{1}$ \\ ${ }^{1}$ Post Graduate and Research Department of Botany, Thiagarajar College, Teppakulam, Madurai - 625009, Tamil Nadu, India \\ ${ }^{2}$ Post Graduate and Research Department of Botany, The American College, Tallakulam, Madurai - 625002, Tamil Nadu, India
}

\section{Article Info:

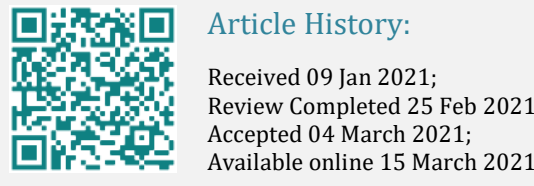

\section{Cite this article as:}

Shanmugam S, Muthupandi CP, Eswaran VM, Rajendran K Medicinal Plants from Vettangudi Water Bird Sanctuary in Sivagangai District of Tamil Nadu, Southern India, Journal of Drug Delivery and Therapeutics. 2021; 11(2):135-140 DOI: http://dx.doi.org/10.22270/jddt.v11i2.4608

\section{Abstract}

Most of the people depending on traditional medicine to meet their primary healthcare needs. Documenting the indigenous knowledge through ethnobotanical studies is important for the conservation of biological resources as well as their sustainable utilization. It is also necessary to collect the information about the knowledge of traditional medicines before it is permanently lost. Having all these facts in mind, the present study was carried out to document the plants used as medicine by the people inhabiting around the Vettangudi Water Bird Sanctuary of Sivagangai district in Tamil Nadu, India. The field survey was conducted in two villages situated near to Vettangudi Water Bird Sanctuary. The medicinal uses of 40 angiospermic plant species belonging to 36 genera of 24 families for various diseases and ailments were recorded by this study. The people inhabiting in the study area used 45 herbal therapies prepared from 40 plants to treat 27 different illnesses. Regarding the plant parts used, leaf was the mostly used plant part (51.16\%) and extract was found as mostly followed mode $(42.28 \%)$ to treat a particular disease. Attention should be made on proper exploitation and utilization of these medicinally important plant species.

Keywords: Medicinal plants, Vettangudi Water Bird Sanctuary, Sivagangai district, Tamil Nadu.

\section{*Address for Correspondence:}

S. Shanmugam, Research Scholar, Post Graduate and Research Department of Botany, Thiagarajar College, 139-140, Kamarajar Road, Teppakulam, Madurai 625009, Tamil Nadu, India.

\section{INTRODUCTION}

The value of medicinal plants to the mankind is very well proven. It is estimated that 70 to $80 \%$ of the people worldwide rely chiefly on traditional health care system and largely on herbal medicines ${ }^{1}$. Scientific investigations of medicinal plants have been initiated in many parts of our country because of their contributions to health care. The tribal and rural people of various parts of India are highly depending on medicinal plant therapy for meeting their health care needs. This is attracting the attention of several botanists and plant scientists who directing vigorous researches towards the discovery or rediscovery of several medicinal plants along with their medicinal remedies for various diseases. Some monumental works have been carried out to enumerate the utility of plants for the treatment of various diseases in different localities of Sivagangai district in Tamil Nadu ${ }^{2-7}$. Yet, there are many sites are remaining to explore the ethnobotanical knowledge in Sivagangai district. In this context, the present study was carried out to enumerate the plants used as medicine by the people inhabiting around the Vettangudi Water Bird Sanctuary of Sivagangai district in Tamil Nadu, India.

\section{MATERIALS AND METHODS}

\subsection{Study area}

The present study was conducted in Vettangudi and S.S. Kottai villages located near to Vettangudi Water Bird Sanctuary of Sivagangai district in Tamil Nadu, Southern India. Vettangudi pond was declared as National Wildlife Reserve in June 1977, since then this pond serves as an ecotourist spot. Thousands of birds migrating from various parts of the country and continents to this pond for a season between the months of November and February comprised of 20 different bird species ${ }^{8}$. Geographically, the entire area of Vettangudi Water Bird Sanctuary is lies between $10^{\circ}$ $0.610^{\prime} \mathrm{N}$ latitude and 78 $01.23^{\prime} \mathrm{E}$ longitude. The altitude of the study area is about 385 feet above mean sea level. The total area of Vettangudi pond is 38.4 ha. Temperature scarcely fluctuates in the year, with the mean monthly 
minimum and maximum temperatures of 24 and $41^{\circ} \mathrm{C}$ respectively, and annual rainfall reaches $15-30 \mathrm{~mm}$

\subsection{Data collection}

The field survey was conducted in different two villages (Vettangudi and S.S. Kottai) situated near to Vettangudi Water Bird Sanctuary for 6 months from July to December, 2019. In the interview survey with 4 herbalist healers and 11 households, the authors used a structured questionnaire. The questionnaire items included each healer's age, their experience of school education and usage of medicinal plants (parts used and mode of preparation) to treat a particular disease. In the case of herbalist healers his/her age at the first practice of herbal therapy was also noted. All the plants were botanically identified with the help of regional floras 9,10 .

\section{RESULTS AND DISCUSSION}

\subsection{Characteristics of healers and households}

According to the interview survey, for the herbalist healers, their age at becoming a healer varied largely. Mostly $(66.67 \%)$ within the age of $35-50$ years, the males became as herbal healers and the females $(100 \%)$ became at above 50 years. It was also revealed that only one-third $(66.67 \%)$ of the healers were educated at school. In the case of households, most of the interview personalities $(63.67 \%)$ who have the tremendous knowledge on the use of plants as medicine were come under the age category of above 50 years and one-fourth $(18.18 \%)$ of the households were educated. The data related to various demographic characteristics of informants were given in Table 1.

Table 1: Percent distribution of the informants based on basic characteristics

\begin{tabular}{|c|c|c|c|c|c|c|}
\hline \multirow{2}{*}{$\begin{array}{l}\text { Basic } \\
\text { characteristics }\end{array}$} & \multicolumn{3}{|c|}{ Herbalist healers } & \multicolumn{3}{|c|}{ Households } \\
\hline & $\begin{array}{l}\text { Male } \\
(n=3)\end{array}$ & $\begin{array}{l}\text { Female } \\
(n=1)\end{array}$ & $\begin{array}{l}\text { Total } \\
(n=4)\end{array}$ & $\begin{array}{l}\text { Male } \\
(n=7)\end{array}$ & $\begin{array}{l}\text { Female } \\
(n=4)\end{array}$ & $\begin{array}{l}\text { Total } \\
(n=11)\end{array}$ \\
\hline \multicolumn{7}{|l|}{ Current age } \\
\hline$<50$ years & 66.67 & 0 & 50.0 & 42.86 & 25.0 & 36.36 \\
\hline$>50$ years & 33.33 & 100.0 & 50.0 & 57.14 & 75.0 & 63.67 \\
\hline \multicolumn{7}{|c|}{ Age at becoming healers } \\
\hline$<35$ years & 0 & 0 & 0 & - & - & - \\
\hline $35-50$ years & 66.67 & 0 & 50.0 & - & - & - \\
\hline$>50$ years & 33.33 & 100.0 & 50.0 & - & - & - \\
\hline \multicolumn{7}{|c|}{ School education } \\
\hline Yes & 33.33 & 0 & 33.33 & 28.57 & 0 & 18.18 \\
\hline No & 66.67 & 100.0 & 66.67 & 71.43 & 100 & 81.82 \\
\hline
\end{tabular}

\subsection{Medicinally important plants}

The present study revealed that 40 plant species of 36 genera belonging to 24 families were found in Vettangudi Water Bird Sanctuary in Sivagangai district possess medicinal values and are used to cure various diseases and ailments like diarrhoea, asthma, fever, jaundice, wounds, stomach pain, cough, cold, poisonous bites, etc. Euphorbiaceae was found as dominant family represented by 4 species, followed by Asclepiadaceae and Solanaceae with 3 species of each. 9 families (Acanthaceae, Aizoaceae, Amaranthaceae, Apocynaceae, Convolvulaceae, Fabaceae, Meliaceae, Moraceae and Myrtaceae) were represented by 2 species and 12 by 1 species (Table 2). The medicinally important plants found in Vettangudi Water Bird Sanctuary, with their family name, local name and medicinal uses were given in the enumeration.

\subsection{Illnesses and herbal therapies}

The people inhabiting in the study area used 45 herbal therapies prepared from 40 plants to treat 27 different illnesses (Table 3). Regarding the plant parts used, leaf is the mostly used plant part $(51.16 \%)$ to treat a particular disease followed by root $(15.54 \%)$, fruit $(8.88 \%)$, entire plant $(6.66 \%)$, seed, stem and stem bark (4.44\% of each). Flower and fruit bark are the least used part $(2.22 \%$ of each). Most of the earlier ethnobotanical studies confirmed that leaves are the major portion of the plant used in the treatment of diseases ${ }^{11-15}$
Table 2: List of families with their no. of genera and species recorded

\begin{tabular}{|l|l|l|}
\hline Name of the family & No. of genera & No. of species \\
\hline Acanthaceae & 2 & 2 \\
\hline Aizoaceae & 2 & 2 \\
\hline Amaranthaceae & 2 & 2 \\
\hline Anacardiaceae & 1 & 1 \\
\hline Annonaceae & 1 & 1 \\
\hline Apocynaceae & 2 & 2 \\
\hline Aristolochiaceae & 1 & 1 \\
\hline Asclepiadaceae & 3 & 3 \\
\hline Asteraceae & 1 & 1 \\
\hline Convolvulaceae & 2 & 2 \\
\hline Cucurbitaceae & 1 & 1 \\
\hline Euphorbiaceae & 3 & 4 \\
\hline Fabaceae & 2 & 2 \\
\hline Malvaceae & 1 & 1 \\
\hline Meliaceae & 2 & 2 \\
\hline Mimosaceae & 1 & 1 \\
\hline Moraceae & 1 & 2 \\
\hline Myrtaceae & 2 & 2 \\
\hline Nyctaginaceae & 1 & 1 \\
\hline Poaceae & 1 & 1 \\
\hline Punicaceae & 1 & 1 \\
\hline Solanaceae & 1 & 3 \\
\hline Verbenaceae & 1 & 1 \\
\hline Vitaceae & 1 & 1 \\
\hline & & \\
\hline & & \\
\hline
\end{tabular}


Table 3: Name of the diseases and botanical name of the plants used.

\begin{tabular}{|c|c|}
\hline Name of the Illness & Name of the plants used \\
\hline Asthma & Adhatoda vasica and Euphorbia hirta \\
\hline Body heat & Cynodon dactylon \\
\hline Body pain & Ficus religiosa \\
\hline Bronchitis & Azadirachta indica \\
\hline Cold & Phyllanthus maderaspatensis, Solanum trilobatum, Solanum torvum and Vitex negundo \\
\hline Cough & Ipomoea aquatica, Solanum trilobatum and Vitex negundo \\
\hline Diabetes & Gymnema sylvestre and Syzygium cumini \\
\hline Diarrhoea & Punica granatum \\
\hline Digestion & Cissus quadrangularis and Solanum nigrum \\
\hline Dysentery & Annona squamosa, Mangifera indica, Psidium guajava and Punica granatum \\
\hline Ear pain & Nerium oleander \\
\hline Fever & Cynodon dactylon, Hemidesmus indicus and Vinca rosea \\
\hline Gastroenteritis & Coccinia grandis \\
\hline Hair growth & Hibiscus rosa-sinensis \\
\hline Heel crack & Ficus benghalensis \\
\hline Hydrocele & Boerhaavia diffusa \\
\hline Intestinal worms & Azadirachta indica \\
\hline Itches & Evolvulus alsinoides \\
\hline Jaundice & Alternanthera sessilis, Eclipta alba, Melia azedarach and Phyllanthus amarus \\
\hline Rheumatism & Pongamia pinnata \\
\hline Skin eruption & Achyranthes aspera and Clitoria ternatea \\
\hline Snake bite & Andrographis paniculata and Aristolochia bracteolata \\
\hline Stomach ulcer & Solanum nigrum \\
\hline Stomach-ache & Syzygium cumini and Trianthema portulacastrum \\
\hline Throat pain & Acalypha indica and Solanum trilobatum \\
\hline Tooth-ache & Acacia nilotica \\
\hline Wound & Calotropis gigantea and Mollugo cerviana \\
\hline
\end{tabular}

The results of present study revealed that the herbal preparations made from the medicinal plants were mostly used for the treatment of cold, dysentery and jaundice ( 4 species respectively), followed by fever and cough (3 species). The study showed that a good number of the collected plants were used for the treatment of multiple diseases. Solanum trilobatum is used for the treatment of three (cold, cough and throat sore) diseases; Azadirachta indica (bronchitis and intestinal worms), Cynodon dactylon (body heat and fever), Punica granatum (diarrhoea and dysentery), Syzygium cumini (diabetes and stomach-ache) and Vitex negundo (cold and cough) are used for the treatment of two diseases; the rest of the plants are used to treat only one disease (Table 3).

Generally, fresh part of the plant is used for the preparation of medicine. In the case of mode of treatment, extract was found as mostly followed mode $(42.28 \%)$ to treat the illness followed by decoction (15.54\%), paste and raw $(11.10 \%$ of each), powder (6.66\%), infusion and latex ( $4.44 \%$ of each) and cooked and oil (2.22\%) (Table 4$)$. These wide range of medicinal preparation to cure the ailment have also been reported from various localities of Tamil Nadu 16-19. 
Table 4: Percent distribution of the plant parts used and mode of treatment

\begin{tabular}{|c|c|c|c|c|c|c|c|c|c|c|c|}
\hline \multirow{2}{*}{$\begin{array}{l}\text { S. } \\
\text { No. }\end{array}$} & \multirow{2}{*}{ Parts used } & \multicolumn{9}{|c|}{ Mode of Treatment } & \multirow{2}{*}{ Total } \\
\hline & & Cooked & Decoction & Extract & Infusion & Latex & Oil & Paste & Powder & Raw & \\
\hline 1 & Entire plant & - & - & 4.44 & - & - & - & 2.22 & - & - & 6.66 \\
\hline 2 & Flower & - & - & - & - & - & - & - & 2.22 & - & 2.22 \\
\hline 3 & Fruit & - & - & - & - & - & - & - & - & 8.88 & 8.88 \\
\hline 4 & Fruit bark & - & - & - & - & - & - & - & 2.22 & - & 2.22 \\
\hline 5 & Leaf & 2.22 & 6.66 & 31.18 & 4.44 & 2.22 & - & 4.44 & - & - & 51.16 \\
\hline 6 & Root & - & 4.44 & 6.66 & - & - & - & 4.44 & - & - & 15.54 \\
\hline 7 & Seed & - & - & - & - & - & 2.22 & - & 2.22 & - & 4.44 \\
\hline 8 & Stem & - & - & - & - & 2.22 & - & - & - & 2.22 & 4.44 \\
\hline 9 & Stem bark & - & 4.44 & - & - & - & - & - & - & - & 4.44 \\
\hline \multicolumn{2}{|c|}{ Total } & 2.22 & 15.54 & 42.28 & 4.44 & 4.44 & 2.22 & 11.10 & 6.66 & 11.10 & 100 \\
\hline
\end{tabular}

\section{ENUMERATION}

In the following enumeration, the plants were arranged alphabetically with their family name, vernacular name (in Tamil) and medicinal uses.

Acacia nilotica L. (Mimosaceae), Karuvelam

Uses: Young twigs are used as a cleaning agent for teeth to cure tooth-ache.

Acalypha indica L. (Euphorbiaceae), Kuppaimaeni

Uses: Leaf decoction is applied for throat pain.

Achyranthes aspera L. (Amaranthaceae), Naayuruvi

Uses: Leaf decoction of plant is applied for skin eruption.

Adhatoda vasica Nees (Acanthaceae), Aadaathodai

Uses: Leaves extract is taken orally twice daily for $30-45$ days to treat asthma.

Alternanthera sessilis (L.) R. Br. ex DC. (Amaranthaceae), Ponnaanganni

Uses: Leaf extract of leaves is given for jaundice until cure.

Andrographis paniculata (Burm.f.) Wallich ex Ness (Acanthaceae), Siriyaanangai

Uses: Leaf Decoction is used for snakebite.

Annona squamosa L. (Annonaceae), Seethaapazham

Uses: Leaf extract is taken orally for $2-3$ days to cure dysentery.

Aristolochia bracteolata Lam. (Aristolochiaceae), Aaduthinnaappaalai

Uses: Leaf extract is applied for snake bite.

Azadirachta indica Adr. Juss. (Meliaceae), Vembu

Uses: Leaf extract is given to drink to wash out intestinal worms. Leaf paste is applied to treat bronchitis.

Boerhaavia diffusa L. (Nyctaginaceae), Mookkirattai

Uses: Root paste is applied externally to cure hydrocele.
Calotropis gigantea (L.) R. Br. (Asclepiadaceae), Yerukku

Uses: Milky latex is applied on the wounds.

Cissus quadrangularis L. (Vitaceae), Pirandai.

Uses: Paste of the whole plant is taken as raw with normal diet for improving the digestion and inducing appetite.

Clitoria ternatea L. (Fabaceae), Sanguppoo

Uses: Leaf infusion with coconut milk is applied for skin eruptions.

Coccinia grandis (L.) J. Voigt (Cucurbitaceae), Kovai

Uses: Fruits are eaten as raw for gastroenteritis.

Cynodon dactylon (L.) Pers. (Poaceae), Arugambull

Uses: Root decoction is given internally to treat fever. Entire plant extract is taken orally in empty stomach to reduce body heat.

Eclipta alba L. (Asteraceae), Karisalaanganni

Uses: Root extract is administered once daily for $25-30$ days for the treatment of Jaundice.

Euphorbia hirta L. (Euphorbiaceae), Ammaan pachcharisi

Uses: Leaf infusion is given to drink with honey to cure asthma.

Evolvulus alsinoides L. (Convolvulaceae), Vishnukarandhai

Uses: Entire plant extract is applied for itches.

Ficus benghalensis L. (Moraceae), Aalamaram

Uses: Stem latex is applied topically on heel cracks.

Ficus religiosa L. (Moraceae), Arasamaram

Uses: Leaf extract is applied to get relief from body pain.

Gymnema sylvestre (Retz.) R. Br. ex Roemer \& Schultes (Asclepiadaceae), Sirukurinjaan

Uses: Leaf extract is taken orally twice a day for up to 1 month to cure diabetes.

Hemidesmus indicus (L.) R. Br. (Asclepiadaceae), Nannaari 
Uses: Leaf extract is given for fever.

Hibiscus rosa-sinensis L. (Malvaceae), Chemparuthi

Uses: Shade dried and powdered flowers are used for cleaning the hair and to prevent hair loss.

Ipomoea aquatica Forsskal (Convolvulaceae), Vallakeerai

Uses: Leaf extract, mixed with honey, is taken internally to cure cough.

\section{Mangifera indica L. (Anacardiaceae), Maamaram}

Uses: Stem bark decoction is given to drink twice a day for 2 days to cure dysentery.

Melia azedarach L. (Meliaceae), Malai vembu

Uses: Leaf extract is extensively used for jaundice until cure.

Mollugo cerviana L. (Aizoaceae), Parpaadagam

Uses: Root paste is applied to heal wounds.

Nerium oleander L. (Apocynaceae), Arali

Uses: Stem bark is boiled with gingerly oil and two drops are poured into ear cure of ear pain.

Phyllanthus amarus Schum. \& Thonn. (Euphorbiaceae), Keelaanelli

Uses: Root decoction is given to drink twice a day for 1 month to cure jaundice.

Phyllanthus maderaspatensis L. (Euphorbiaceae), Maelaanelli

Uses: Root decoction of is taken orally for cold.

Pongamia pinnata (L.) Pierre (Fabaceae), Pungam

Uses: Seed oil is applied used to cure rheumatic pains and swellings.

\section{Psidium guajava L. (Myrtaceae), Koyyaa}

Uses: Fruits are eaten as raw to treat dysentery.

\section{Punica granatum L. (Puniacaceae), Maadhulam}

Uses: The powder of fruit bark is given with water for treating diarrhoea and blood dysentery.

\section{Solanum nigrum L. (Solanaceae), Manathakkaali}

Uses: Fruit are eaten as raw for digestion. Leaves are cooked and eaten with normal diet to cure stomach ulcer.

\section{Solanum trilobatum L. (Solanaceae), Thoodhuvalai}

Uses: Leaf extract is taken orally to cure cold and cough. Leaf paste is applied externally to treat throat infection.

\section{Solanum torvum Sw. (Solanaceae), Sundaikkaai}

Uses: Leaf extract is administered orally to get relief from cold.

Syzygium cumini (L.) Skeels (Myrtaceae), Naaval.

Uses: Fruits are eaten as raw to treat stomach-ache. Decoction of dried seed is taken orally for diabetes until cure.

Trianthema portulacastrum L. (Aizoaceae), Saaranathi

Uses: Root extract is given to drink used to cure stomach pain.

Vinca rosea L. (Apocynaceae), Nithiyakalyaani

Uses: Leaf extract is taken orally with milk twice a day to treat fever.
Vitex negundo L. (Verbenaceae), Notchi

Uses: Vapour when leaves are burn is inhaled to treat cold and cough.

\section{CONCLUSION}

The results of this study will now provide information on medicinal plants for possible on-farm conservation. Since most of them are herbs, they grow fast and therefore can provide a continuous supply of the medicinal products. When household needs are met the surplus can be sold for income generation. Some of these species are leguminous and hence will also contribute to soil fertility due to their ability to fix nitrogen. These species can be grown on farm edges or on the boundaries, where there is little interference with crop plants. These plants can become an additional source of income for the people, if they are made aware of the medicinal importance of these plants.

The findings of this study also become basic leads for chemical, pharmacological, clinical and biochemical investigations, which ultimately may birth to drug discovery. Therefore, phytochemical and pharmacological values of these medicinally important plants should be tested. At the same time, over exploitation of plant species in the name of medicine may lead some species ultimately to the disappearance in future. Therefore, attention should also be made on proper exploitation and utilization of these plants.

\section{ACKNOWLEDGEMENT}

The authors are cordially grateful to the informants of the study area because of their kind support and co-operation during the field trips.

\section{CONFLICT OF INTEREST}

The authors have declared that there is no conflict of interest.

\section{REFERENCES}

1. Shanley P \& Luz L. The impacts of forest degradation on medicinal plant use and implication for health care in Eastern Amazonia. BioScience, 2003; 53(6):573-584.

2. Shanmugam S, Manikandan K \& Rajendran K. Ethnomedicinal survey of medicinal plants used for the treatment of diabetes and jaundice among the villagers of Sivagangai district, Tamil Nadu. Ethnobotanical Leaflets, 2009; 13:186-193.

3. Shanmugam S, Kalaisevan M, Selvakumar P, Suresh K \& Rajendran K. Ethnomedicinal plants used to cure diarrhea and dysentery in Sivagangai district of Tami Nadu, India. International Journal of Research in Ayurveda and Pharmacy, 2011; 2(3):991-994.

4. Shanmugam S, Rajendran K \& Suresh K. Traditional uses of medicinal plants among the rural people in Sivagangai district of Tamil Nadu, Southern India. Asian Pacific Journal of Tropical Biomedicine, 2012; 2:S429-S434.

5. Shanmugam S, Balamurugan S, Pandiselvam P \& Rajendran, K. Medicinal plants used by the people of Thiruppuvanam and its surrounding areas of Sivagangai district in Tamil Nadu, Southern India. Journal of Basic Applied Biology, 2012; 6:39-45.

6. Shanmugam S, Sundari A, Muneeswaran S, Vasanth C, Jayakumararaj R \& Rajendran K. Ethnobotanical indices on medicinal plants used to treat poisonous bites in Thiruppuvanam region of Sivagangai district in Tamil Nadu, India. Journal of Drug Delivery and Therapeutics, 2020; 10(6s):31-36.

7. Shanmugam S, Sundari A, Jayakumararaj R \& Rajendran K. Ethnomedicinal survey of plants used for oral and dental healthcare in Sivagangai district, Tamil Nadu, Southern India International Journal of Scientific Research in Biological Sciences, 2020; 7(6):141-146. 
8. Karthick A. Wildlife Study at Vettangudi Birds' Sanctuary, B.Sc., Dissertation, Thiagarajar College, Madurai, Tamil Nadu, India, 2009.

9. Matthew KM. Flora of Tamil Nadu Carnatic. The Rapinat Herbarium, St. Joseph's College, Tiruchirapalli, Tamil Nadu, India, 1983.

10. Matthew KM. An Excursion Flora of Central Tamil Nadu. Oxford and IBH Publishing Co. Pvt. Ltd., New Delhi, India, 1991.

11. Ayyanar M, Sankarasivaraman K \& Ignacimuthu S. Traditional herbal medicines used for the Treatment of diabetes among two major tribal groups in South Tamil Nadu, India. Ethnobotanical Leaflets, 2008; 12:276-280.

12. Ignacimuthu $S$, Ayyanar $M$ \& Sankarasivaraman $K$ Ethnobotanical study of medicinal plants used by Paliyar tribals in Theni district of Tamil Nadu, India. Fitoterapia, 2008; 79:562568.

13. Ayyanar M, Sankarasivaraman K \& Ignacimuthu S. and Sekar T. Plant species with ethnobotanical importance other than medicinal in Theni district of Tamil Nadu, Southern India. Asian Journal of Experimental and Biological Sciences, 2010; 1(4):765771.

14. Rajendran K \& Gunasekaran T. Common and cultivated medicinal plants and their utilization by villagers in southern district of Tamil Nadu. The Indian Forester, 2006; 132(12):16311637.

15. Rajendran K, Balaji P \& Jothibasu M. Medicinal plants and their utilization by villagers in Southern districts of Tamil Nadu. Indian Journal of Traditional Knowledge, 2008; 7(3):417-420.

16. Shanmugam S, Rajagopal V \& Rajendran K. Multipurpose usable plants in Thalaiyanai hills of Tirunelveli forest division in southern part of Western Ghats. Journal of Non-Timber Forest Products, 2007; 14(4):297-306.

17. Shanmugam S, Ramar S, Ragavendhar K, Ramanathan R \& Rajendran K. Plants used as medicine by Paliyar tribes of Shenbagathope in Virudhunagar district of Tamil Nadu. Journal of Economic and Taxonomic Botany, 2008; 32(4):922-929.

18. Shanmugam S, Annadurai M \& Rajendran K. Ethnomedicinal plants used to cure diarrhea and dysentery in Pachalur hills of Dindigul district in Tamil Nadu, Southern India. Journal of Applied Pharmaceutical Sciences, 2011; 1(8):94-97.

19. Shanmugam S, Jeyaprabakaran G \& Rajendran K. Medicinal trees from home gardens of urban areas in Madurai district of Tamil Nadu, Southern India. Asian Journal of Ethnobiology, 2020; $3(1): 10-15$. 